\title{
Erratum to: IkBa mediates prostate cancer cell death induced by combinatorial targeting of the androgen receptor
}

\author{
Sarah L. Carter ${ }^{1}$, Margaret M. Centenera ${ }^{1,2}$, Wayne D. Tilley ${ }^{1}$, Luke A. Selth ${ }^{1}$ and Lisa M. Butler ${ }^{1,2^{*}}$
}

\section{Erratum}

After publication of the original article [1], the authors requested a change in name format: for the middle name initials, and not the full author names, to be used. This has been changed here and in the original manuscript.

Received: 25 February 2016 Accepted: 25 February 2016

Published online: 03 March 2016

\section{Reference}

1. Carter SL, Centenera MM, Tilley WD, Selth LA, Butler LM. IKBa mediates prostate cancer cell death induced by combinatorial targeting of the androgen receptor. BMC Cancer. 2016;16:141. doi:10.1186/s12885-016-2188-2.

\footnotetext{
* Correspondence: lisa.butler@adelaide.edu.au

'Dame Roma Mitchell Cancer Research Laboratories, Adelaide Prostate Cancer Research Centre and Freemason's Foundation Centre for Men's Health, School of Medicine, University of Adelaide and Hanson Institute, Adelaide, SA 5005, Australia

${ }^{2}$ Cancer Theme, South Australian Health and Medical Research Institute, Adelaide, SA 5001, Australia
}

Submit your next manuscript to BioMed Central and we will help you at every step:

- We accept pre-submission inquiries

- Our selector tool helps you to find the most relevant journal

- We provide round the clock customer support

- Convenient online submission

- Thorough peer review

- Inclusion in PubMed and all major indexing services

- Maximum visibility for your research

Submit your manuscript at

www.biomedcentral.com/submit \section{.}

